\title{
An Analysis of Recent Trends in Tourist Arrivals in Sri Lanka
}

\author{
By Kumudika K. E. Perera*
}

\begin{abstract}
According to the Annual Statistical Report (2014) which published by the Sri Lanka Tourism Development Authority (SLTDA), tourist arrivals in Sri Lanka increased from 1,274,593 in 2013 to 1,527,153 in 2014, which is an increase of 19.8 percent. This paper aims to discuss the overall trends in tourist arrivals, to identify the recent trends in profile characteristics of tourist arrivals and to analyze the trends in tourist arrivals by different regions. Overall trends delineated in this article are based on the statistical data from 1986 to 2015. Recent trends in profile characteristics of tourist arrivals are discussed within the six categories: seasonality of arrivals; gender; age; purpose of visit; occupational categories and period of stay that based on the statistical data from 2001 to 2015. The data was analyzed using time series analysis, applying the ordinary least square linear regression method as well as 12-month moving average. The results of the data analysis revealed, that tourist arrivals in Sri Lanka has shown a moderate increasing trend during the period from 1986 to 2015. In seasonality of arrivals, the period from January to March and the month of December marked as a peak seasons while May and June as lean months.The overall picture showed that the tourists, especially younger tourists have demonstrated a decreasing trend and older tourists have demonstrated an increasing trend to visit Sri Lanka during the period of study. The study also revealed that the trends in percentage distribution of female and male representation were respectively positive and negative. The majority of the tourists who arrived in Sri Lanka during the period were gainfully occupied. At the regional level, tourist arrivals from South Asia, Eastern Europe, Middle East and Australasia regions have represented a remarkable increase.
\end{abstract}

Keywords: Tourism, Foreign exchange, Tourist arrivals, Sri Lanka, trends, profile characteristics, moderate, remarkable

\section{Introduction}

According to Goeldner and Ritchie (2009) "Tourism is a composite of activities, services and industries that deliver a travel experience: transportation, accommodations, eating and drinking establishments, shops, entertainment, activity facilities and other hospitality services available for individuals or groups that are traveling away from home". When considering the definition of the United Nations World Tourism Organization (UNWTO), according to the SESRIC (2010) "international tourism comprises the activities of persons traveling to and staying at places outside their usual permanent places of residence for a period not exceeding 12 months for leisure, business and other purposes". However, not to make profit in the place visited. In additionally,

${ }^{*}$ Former Assistant Lecturer, Department of Geography, University of Colombo, Sri Lanka. 
according to the Statistical Abstract (2015) which published by Department of Census and Statistics in Sri Lanka, the term of "International Tourists" (overnight visitors) refers to an international visitor who stays at least one night (but not more than 365 nights consecutively) in a collective or private accommodation in the country visited. Further, DCS (2015) defines "every single visit (or entry) of a tourist to the country either in the course of the same trip or in the course of different trips is counted as a tourist arrival, provided the visit (or entry) lasts at least one night in the country. However, those who do not cross the frontiers are not regarded as visitors".

In particular, tourism is one of the largest and fastest growing industries in the world (Neto, 2003). Further, it continues to expand annually. Therefore, it can be identified as an increasing source of income. In fact, many developing countries have seen their tourist arrivals increase significantly (UNWTO and $S N V, 2010$ ). For example, arrivals to developing countries accounted for 46 per cent of the total international arrivals in 2011 (UNWTO and SNV, 2010). Nevertheless, according to the World Tourism Organization (2014) international tourism is set to hit a new record by the end of 2014 with over 1.1 billion international tourists travelling the world in one single year. Moreover, according to the World Tourism Organization (2016) the number of international tourist arrivals (overnight visitors) in 2015 increased by 4.6 per cent to reach a total of 1186 million worldwide, an increase of 52 million over the previous year. Specially, arrival of tourists is important to the economy of a country. Furthermore, arrival of tourists also uplifts the overall living standard of the society.

When focused on Sri Lanka, tourism is among the most important source of foreign exchange for Sri Lankan economy (ICRA Lanka and IMACS, 2011). In fact, tourism was ranked as the fifth largest source of foreign exchange earnings in 2012, and third largest in 2013 contributing 5.2 per cent to total foreign earnings of the country (Welgamage and Perera, 2015). Therefore, the foreign exchange earnings from tourism increased by 66.9 per cent from LKR 132,427 million (US \$ 1,038.3 million) in 2012 to LKR 221,147.1 million (US \$ 1,715.5 million) in 2013 (SLTDA, 2013). In addition, Sri Lanka Tourism has surged to a new high record of 1,798,380 arrivals in 2015, transcending all time high hits in the history, which is an increase of 17.8 per cent over last year's 1,527,153 arrivals (SLTDA, 2015). The portion of tourism's contribution to total foreign exchange earnings in 2015 amounted to 12.4 per cent. The foreign exchange earnings increased by 27.72 per cent from Rs. 317,479 million (US \$ 2,431.1 million) in 2014 to Rs. 405,492 million (US $\$ 2,980.6$ million) in 2015 (SLTDA, 2015).

According to the Central Bank of Sri Lanka (2015), Sri Lanka shares 0.13 per cent of the total tourist arrivals and 0.2 per cent of the total tourist earnings of the world in 2014. Therefore, great potential lies ahead since Sri Lanka has grasped only a fraction of the world tourism at present. Traditionally, the natural beauty, comfortable climate, historical and cultural heritage and religious diversity are considered as areas of growth potentials in the tourism industry of Sri Lanka. Further, the success of tourism is greatly dependent on 
the security and safety of a country. At present, Sri Lanka is among the few tourist destinations left in the world without any threat of terrorism. In addition, Sri Lanka is blessed with $1,500 \mathrm{~km}$ of coastal belt, yet, it has not been utilized to realize its true potential. Therefore, high potential exists in niche segments of tourism such as MICE (Meeting, Incentives, Conferences and Events) tourism, Health tourism, Eco tourism, Adventure tourism, Leisure tourism, Agro tourism, Cruise and Marine tourism, Village and Urban tourism and Recreational tourism in Sri Lanka (Central Bank of Sri Lanka, 2015).

In general, tourist statistics are very important as it helps the tourism organization in a variety of ways. These statistics are required for planning as well as for marketing and promotional purposes of tourism. For example, according to Jayapalan (2001) statistics of characteristics are yet another type of tourist statistics, which are very essential for those concerned with marketing and development of tourism. In additionally, any information regarding the markets, the mode of transport used and the socio-economic characteristics of the visitors are all essential for tourism planning and development. The total volume of arrivals and tourist nights have to be divided into various market segments according to the purpose of visit, mode of transport used, place of origin, tourist profile characteristics and tourist behavior patterns in order to provide meaningful information for marketing and development purposes. In particular, the main profile characteristics of tourists include age, sex, occupation and income (Bhatia, 2006). According to the Sri Lanka Tourism Development Authority (former "Sri Lanka Tourist Board"), the main profile characteristics of tourists are seasonality of arrivals; mode of transport and port of arrival; arrivals by carrier; purpose of visit; average duration of stay and tourist nights; age \& sex distributions, and occupation.

In this context, it is interesting to find out the recent trends in profile characteristics of tourist arrivals in Sri Lanka. It is important for the development of future tourism industry in Sri Lanka. Furthermore, it is also important to help in creating demand for hotel accommodation and infrastructure development by the government. In addition to that, it is important to the development of various new tourism destinations for the betterment of the tourism industry. Similarly, identifying the recent trends in tourist arrivals in Sri Lanka is important and valuable to prove the economic development and job creation, because, strong growth in tourist arrivals reflects on economic activities that generated by industries such as hotels, restaurants, leisure industries, travel agents, airlines, airports and other passenger transportation services. In general, tourism is capable of providing employment opportunities for a large number of poorly educated or unskilled workers, a characteristic that applies to many rural areas in Sri Lanka (Tisdell and Bandara, 2004). Hence, the main objective of this study is to analyze the recent trends in tourist arrivals in Sri Lanka. The specific objectives of the study are: 1) to analyze overall trends in the number of tourist arrivals; 2) to examine trends in the percentage distribution of tourists by profile characteristics; 3) to analyze trends in annual tourist arrivals by different regions. 
The paper consists of five chapters. The first chapter presents an introduction of the study. Chapter two reviews the relevant literature while chapter three is reserved to describe the methodological choice for the study. Chapter four presents the data analysis and Chapter five summarizes the entire study.

\section{Literature Review}

When considering Sri Lanka, there are many factors that affect the tourist arrivals. Traditionally, Sri Lanka's diverse landscapes and rich cultural heritage present a wide range of tourism opportunities, ranging from "sun and beach" holidays, wildlife excursions, and cultural tours (Ranasinghe, 2015). As already mentioned, Sri Lanka has 49 sites classified as unique attractions, 91 as rare attractions and eight world heritage sites. The eight heritage sites are: 1) Ancient City of Polonnaruwa; 2) Ancient City of Sigiriya; 3) Golden Temple of Dambulla; 4) Old Town of Galle and its Fortifications; 5) Sacred City of Anuradhapura; 6) Sacred City of Kandy; 7) Central Highlands of Sri Lanka and 8) Sinharaja Forest Reserve (ICRA Lanka and IMACS, 2011). In addition, the country has a unique mixture of golden sandy beaches; abundant wildlife; dramatic mountain ranges; cascading waterfalls; blue green landscapes; rejuvenating cool air; botanical gardens; cultural orientation; respect for people and traditions; religious values and lot of sacred sites. The attractive coastal areas like Tangalle, Hambantota, Pasikuda, Unawatuna, Arugam Bay and beautiful coral reefs at Hikkaduwa have attracted the tourists (Educational Publications Department, 2015).

Furthermore, Oceanic waters around Sri Lanka support populations of whales and dolphins, including the Blue whale and the Sperm whale. Offering opportunities for establishing whale watching as a commercial tourist activity. Migrant birds and marine turtles, which come ashore for nesting lend further support to the enhancement of ecotourism initiatives, particularly in the south. In addition to ecotourism, the Sri Lankan tourism industry is keen to promote other special interest tourism, such as the local Ayurveda health packages (Fernando and Shariff, 2013).

Moreover, according to the web site of Lanka Walker (2016), due to varying climate conditions and geography, Sri Lanka is an ideal destination for sports tourism at present. Some of the popular sports include golf; surfing; diving and snorkeling; hot air ballooning; rafting and canoeing; white water rafting; scuba diving; fishing; cycling; hiking; trekking and rock climbing. Specifically, Sri Lanka is often referred as "the pearl of the Indian Ocean" because of its beautiful shape and geographical location. Further, many travel journalists have referred to Sri Lanka as "the Paradise of Earth" or "the Jewel of Asia" (Ministry of Economic Development, 2010). All these lead to one conclusion, that Sri Lanka is a natural wonder and it is the reason for tourists' attraction and the rise in tourist arrivals. Therefore, Sri Lanka has many tourist attraction locations (See Figure 1). Sri Lanka also has seven major tourism 
zones as Colombo City, Greater Colombo, Southern Coast, East Coast, Central Highlands, Ancient Cities and Northern Region (Sri Lanka Tourism Development Authority, 2014).

Figure 1. Sri Lanka Tourist Attractions

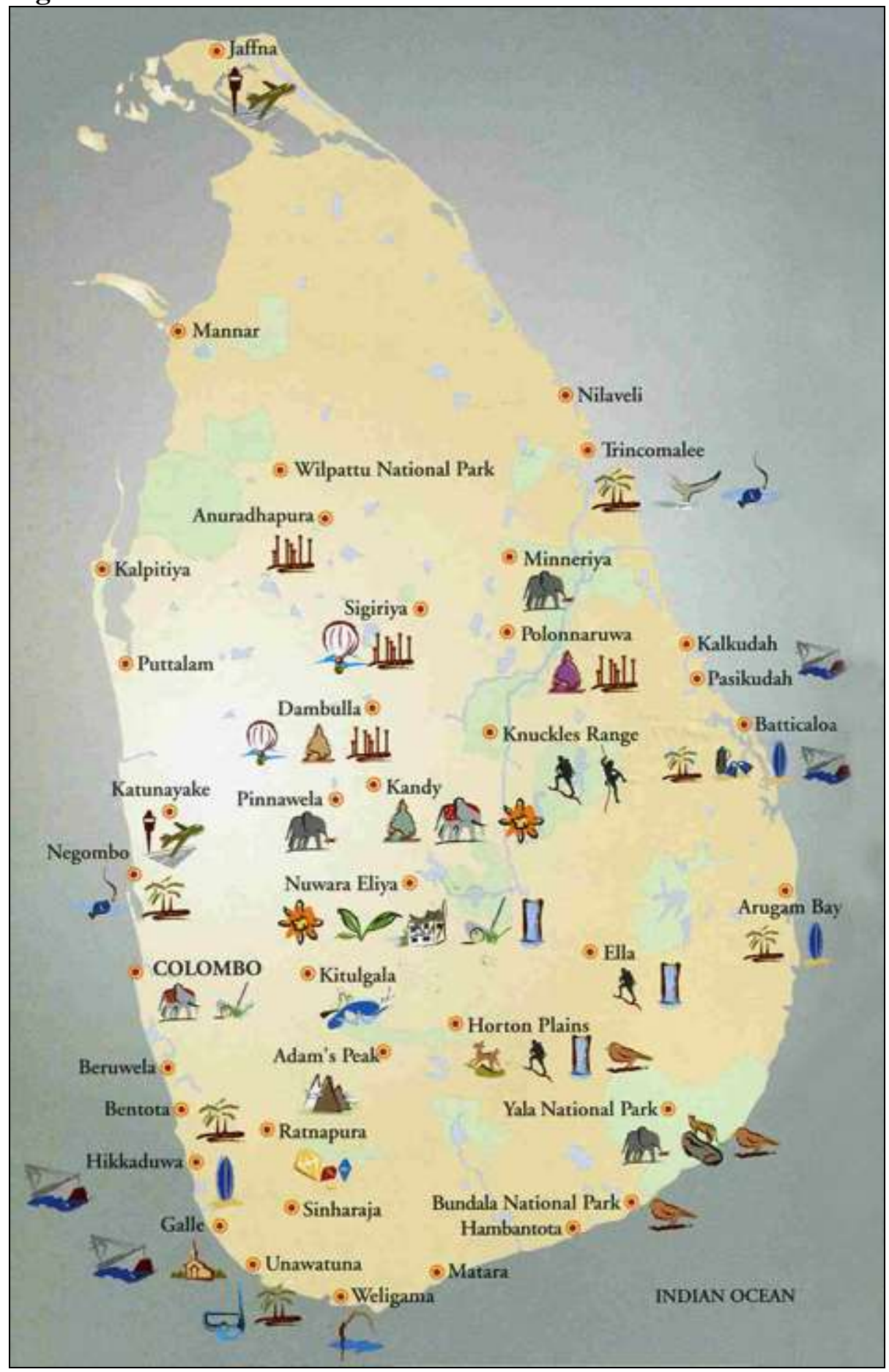

Source: www.sltda.lk, 10.09.2016 
Figure 2. Major Tourism Zones in Sri Lanka

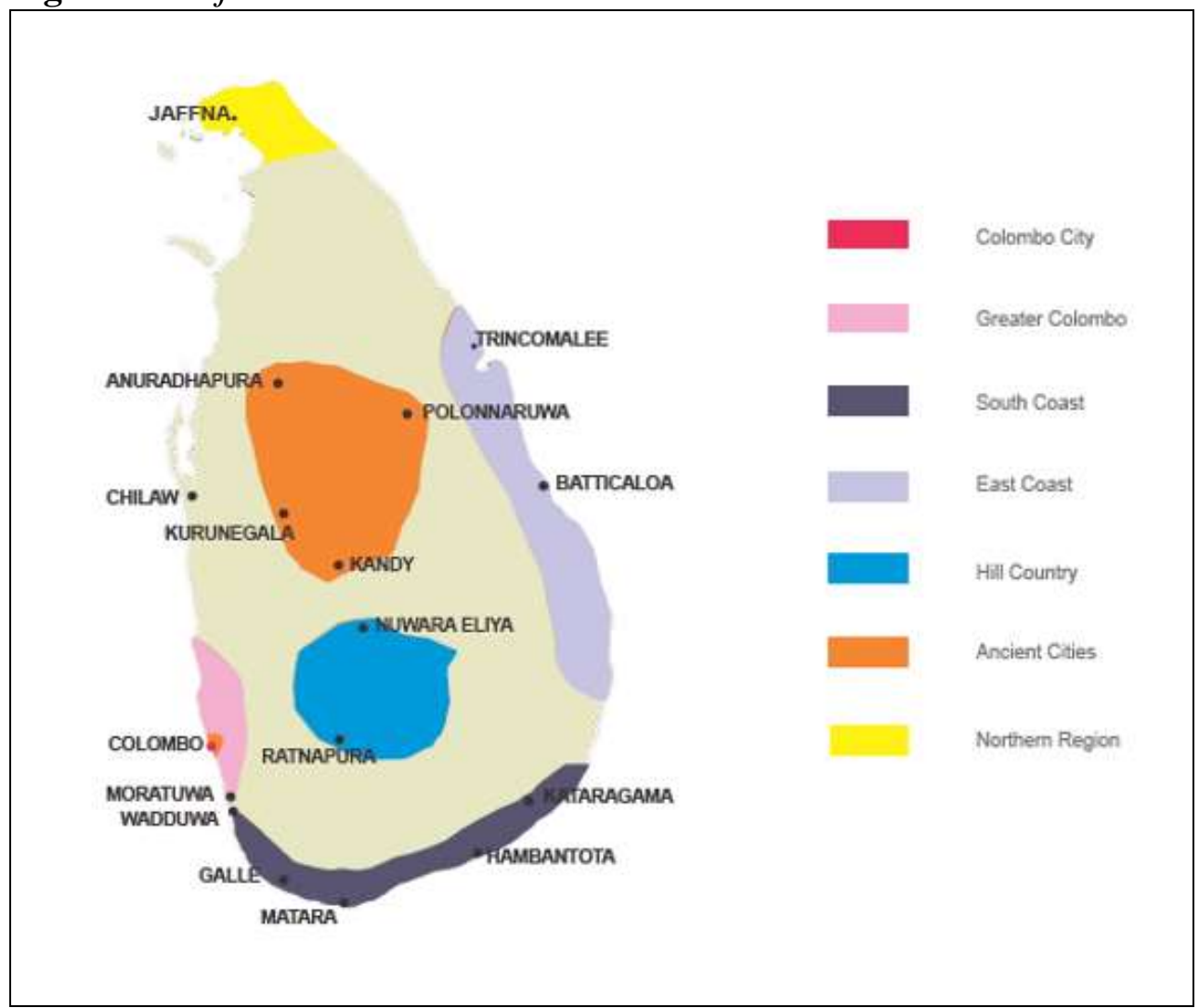

Source: Annual Statistical Report, SLTDA, 2014

Certainly, the success of tourism is greatly dependent on the security and safety of a country (Annual Report of the Central Bank of Sri Lanka, 2015). At present, in Sri Lanka, following the ending of the 30-year conflict and liberalization of Northern and Eastern provinces in May 2009, tourist arrivals recorded tremendous growths of 46 per cent and 31 per cent in 2010 and 2011 respectively (SLTDA, 2012).

Various researchers have recently engaged many studies of international tourism that focus on trends in tourist arrivals. Fundamentally, the literature on forecasting and identify the trends in tourist arrivals is huge with various type of empirical analyses. Many of the researchers have used time series approaches where the objective is to analyze the trends in tourist arrivals. The literature review is related with the objectives of the current study covering some major areas as follows:

Ismail, Velnampy and Mustafa (2012) released an article that focus on the relationship between years \& number of tourists' arrivals and forecast number of tourist arrivals during the next five years in Sri Lanka. Data have been recorded in order starting from 2000 to 2010 and analyzed using Descriptive statistics and Pearson Correlation Simple regression. 3-year simple moving average was calculated for finding the forecasted data from 2011 to 2015 . The results provided in the article suggest that the number of tourists who visited to Sri Lanka have increased from early 2001 to 2004. The authors also stated that 
there was a slight decline in the year 2005 than year 2004. A further decline started from 2006 to 2008. Increase started from 2009 onwards. Therefore, the authors concluded that the peace has helped in increasing number of tourists' arrivals during the last decade. According to the forecasting, Forecasted number of tourist during 2011 to 2015 would be more than 510, 000. It would be a positive sign for the growth of tourism industry in Sri Lanka.

Angappapillai and Shanmugasundram (2013) conducted a study to examine the seasonal, cyclical, irregular variations and the secular trend in tourist arrivals in Thanjavur District, India. In the study, seasonal variations in the tourist arrivals are studied for 10 years from $2001-2002$ to $2010-2011$ by applying the moving average method. Further, to test the significance of the trend over time, the linear regression equation has been formed. The results provided that while tourist arrivals, both domestic and foreign in Thanjavur show a relatively stable trend of growth over a period under study and tourist arrivals in Tamil Nadu have witnessed fluctuations. However, the trend coefficient of foreign tourist arrivals is not statistically significant. It showed that foreign tourist arrivals in Thanjavur region are not very significant during the period under study. A significant positive trend has been observed in the case of domestic tourist arrivals in the region. The analysis has revealed that period from April to June marks a lean period of foreign tourist arrivals in the district. The peak season for arrivals has been found to be August to December.

Dhakal (2013) released an article that reviewed the trend of tourist arrivals in Nepal. This study investigated the trend of tourist arrival, average length of stay, purpose of visit, seasonal trend of tourist arrival and tourist arrival by major nationalities in Nepal. The data were analyzed in the five-year age interval from 1962 to 2012 and Simple statistical tools were applied for data analysis. The results provided in the article suggest that the trend of tourists visiting Nepal seems satisfactory. Despite the relative stagnancy and fluctuations, tourist's influx showed a steady trend in most of the occasions. The author stated that the average length of stay of tourists in Nepal is about 11 days. The author also stated that most of the tourists visiting Nepal come for holiday/pleasure purpose. Since the beginning above 75 per cent, tourists of arriving Nepal came with the holiday/pleasure purpose and it continued until 1990. In addition, the number of tourists coming for trekking/mountaineering purpose has been increasing with the share growing from 0.4 per cent in 1965 to 13.1 per cent in 2012. The sex wise trend of tourist arrivals in Nepal showed that the number of male tourists is larger than that of female tourists. According to the age category, in the early periods the highest share was occupied by the younger age group 16-30 followed by the age group of 31-45, 46-60 \& over and 0-15 since 1965 to 1990 except in 1985 tourist arrivals trend in Nepal. But since the year 1992 to 2012 the trend showed that the age group of 31-45 has a higher share and age group and followed by 16-30, 46- 60, 61 and $0-15$ age group. The author concluded that Nepal is popular both for youths and adults visitors. The author also stated that March - April of spring season and October - November of autumn season were the four months with peak seasons for tourist coming to Nepal. The lowest arrivals were in the 
month of June and July. However, recently there was indication that tourists are coming to Nepal slowly in other seasons too.

Fernando et al. (2013) released an article that focused on Political violence and volatility in international tourist arrivals in Sri Lanka. The study was comprised monthly international tourist arrivals from January 1967 to July 2012. The Generalized Autoregressive Conditional Heteroskedasticity (GARCH) model has been used to analyze Sri Lankan monthly international tourism arrival data and to capture the volatility characteristics inherent within it. The results showed that a significant seasonal effect in tourist arrivals in Sri Lanka. Significant seasonal dummy variables with negative coefficients for April, May and September showed that there was a decline in tourist arrivals in these months compared to months without seasonal variation. Peak levels of tourist arrivals were observed in November to January. The respective dummy variables in these months were significant at the 5\% level and they do, as expected, having a positive sign. The authors also stated that the apart from a mini peak in tourist arrivals in July and August due to the cultural pageant in the Hill Capital of Sri Lanka, Kandy, months from April to September can be considered as a season with low tourist arrivals. Furthermore, the results suggested that major war-related incidents are strong enough to reduce the tourist arrival numbers by $5.2 \%$ per month compared to a period when peace is restored in the country.

Kurukulasooriya and Lelwala (2014) investigated that the time series behaviour of international tourist arrivals and thereby to investigate the trend pattern and the pattern of seasonality of tourist arrivals for the period from July 2009 to July 2013. Mann-Kendall test, multiplicative decomposition model and ratio-to-moving-average method have been used for the data analysis. The authors have also estimated alternative seasonal indicators for a comparative analysis, including the Gini-coefficient. The authors identified that there was an increment of tourist arrivals from January to February and April to July. For all other months, there were some reductions in tourist arrivals compared to the monthly averages. The high hit is reported in July each year within the post war period while the lowest record is in December. The authors also identified that the tourist arrivals have significantly risen in the months of February, June, July and August while months of September and October were identified as mini peak for arrivals. Gini coefficients have been varied from 0.11 to 0.13 and they indicated a substantial seasonal variation of the tourist arrivals distribution for the given years. According to the multiplicative model, three month ahead ex ante forecasts were generated for the next three months covering July $(110,961)$, August $(98,849)$ and September $(82,911)$ in 2013. The ex-ante forecasts have been suggested that the flow of international tourists to Sri Lanka for each respective month will continue to increase and follow similar patterns of seasonal arrivals. 


\section{Research Methodology}

\section{Study Area}

The Democratic Socialist Republic of Sri Lanka is located in the Indian Ocean, between $5^{0} 55^{\prime}$ and $9^{0} 51^{\prime}$ of North Latitude and $79^{0} 42^{\prime}$ and $81^{0} 52^{\prime}$ of East Longitude, at the base of the Indian Sub-Continent, approximately $32 \mathrm{~km}$ to the Southeast of India and $880 \mathrm{~km}$ North of the Equator. Its area is approximately $65,610 \mathrm{Sq} . \mathrm{km}$. with a beautiful coastline of about 1,620 km (Fernando and Shariff, 2013).

According to Lai (2002), Sri Lanka is a tropical country with distinct dry and wet seasons. The island has two monsoon seasons: the southwest monsoon lasts from late May to late September and the northeast monsoon affects the northeast coasts from December to March. According to the Department of Meteorology, Sri Lanka (2015), the average annual rainfall has a considerable spatial variation. There is a drop in temperature with elevation. In the lowlands, the climate is generally humid with an average temperature of $27^{\circ} \mathrm{C}$. At a higher altitude, however, the central hill country enjoys a mild and pleasant climate with a temperature ranging from $10-16^{\circ} \mathrm{C}$ (Lai, 2002). Therefore, the geographical identity of Sri Lanka is further emphasized by the scenic beauty and the different relief systems as well as by the favourable climatic conditions. The relief and the diversity of climate attract tourists to this country (Educational Publications Department, 2015).

The population of Sri Lanka was 20.48 million in 2013 including Sinhalese (74.9\%); Sri Lankan Tamils (11.2\%); Indian Tamils (4.2\%); Sri Lankan Moors $(9.2 \%)$ and Malays and others $(0.5 \%)$. Therefore, Sri Lanka has a diverse religious mix with Buddhist, Hindu, Islam and Christian (Department of Statistics, 2014).

\section{Data Collection}

This study is mainly based on secondary data. Secondary data were collected from the Annual Statistical reports published by the Sri Lanka Tourism Development Authority (former "Sri Lanka Tourist Board"). Monthly tourist arrivals data were collected for the 30-year period from 1986 to 2015. Annual percentage distribution of tourist arrivals data were collected for the 15-year period from 2001 to 2015 according to selected main profile characteristics of tourists. The study is limited to the five main profile characteristics as: seasonality of arrivals; purpose of visit; period of stay; age \& sex distributions, and occupational categories. However, monthly tourist arrivals data were collected to examine trends in seasonality of arrivals for the 30-year period from 1986 to 2015. In addition, annual tourist arrivals data by different regions were collected for the 15-year period from 2001 to 2015 . 


\section{Methods of Analysis}

In analyzing the trends in tourist arrivals, a number of statistical methods have been used in the literature. These methods mainly include moving average method (Ismail, Velnampy \& Mustafa, 2012; Angappapillai \& Shanmugasundram, 2013; Kurukulasooriya \& Lelwala, 2014), regression analysis (Ismail, Velnampy \& Mustafa, 2012; Angappapillai \& Shanmugasundram, 2013; Kurukulasooriya \& Lelwala, 2014), simple statistical tools (Dhakal, 2013), GARCH model (Fernando et al., 2013), multiplicative decomposition model (Kurukulasooriya \& Lelwala, 2014), Gini coefficient (Kurukulasooriya \& Lelwala, 2014) and Descriptive statistics (Ismail, Velnampy \& Mustafa, 2012).

Therefore, the current study proposes the same statistical techniques since the trend analysis and seasonality analysis of tourist arrivals. Statistical analysis such as 12 months moving average, linear regression and time series analysis methods were used to analyze periodic changes in both annual and seasonal contexts. Especially, a common feature of time series data is a trend. Using regression, we can model and forecast the trend in time series data. Linear regression analysis has many advantages. First, it is simple to estimate and use. Regression analysis, in addition to its primary use for the purpose of prediction, can also be used to study the nature of the relationship between a dependent variable and an independent variable, to quantify the effect that changes in the independent variable have on the dependent variable and to identify unusual observations. Second, it can be good first order approximation to more complex forms. A regression based trend analysis is conducted using linear trend model that are given in equation.

$$
Y=m x+c
$$

Where $m$ represents the rate of changes and $c$ represents the $y$ intercept of the line. The $\mathrm{R}$-squared $\left(\mathrm{R}^{2}\right)$ value ranging from ' 0 ' to ' 1 ' or the 'corrected $\mathrm{R}$ squared' $\left(\mathrm{R}^{2}\right)$ which is adjusted for degrees of freedom indicates the explanatory power (goodness of fit) of the model.

The influence of the seasonal component of time series values is identified by determining the seasonal index number associated with each season (a month in this study) of the year. The most frequently used procedure to determine seasonal index is the ratio-to-moving-average method. In the current study, in order to analyze the trend, the data on tourist arrivals were subjected to 12 months moving average. 


\section{Results and Discussion}

\section{Trends in the Number of Tourist Arrivals}

In order to analyze overall trends in the number of tourist arrivals, the annual tourist arrivals data were obtained from the Annual Statistical Reports published by the Sri Lanka Tourism Development Authority (SLTDA). Data were collected for the period from 1986 to 2015. Particularly Linear Regression analysis was carried out for the annual total number of tourist arrivals.

According to the Figure 3, it is evident that the overall trend in the number of international tourist arrivals in Sri Lanka shows a moderate increasing (positive) trend throughout the previous three decadal periods with the rate of 34387 arrivals per year and $R^{2}$ value of 0.615 .

Figure 3. Trends in Number of Tourist Arrivals by Year - 1986 to 2015

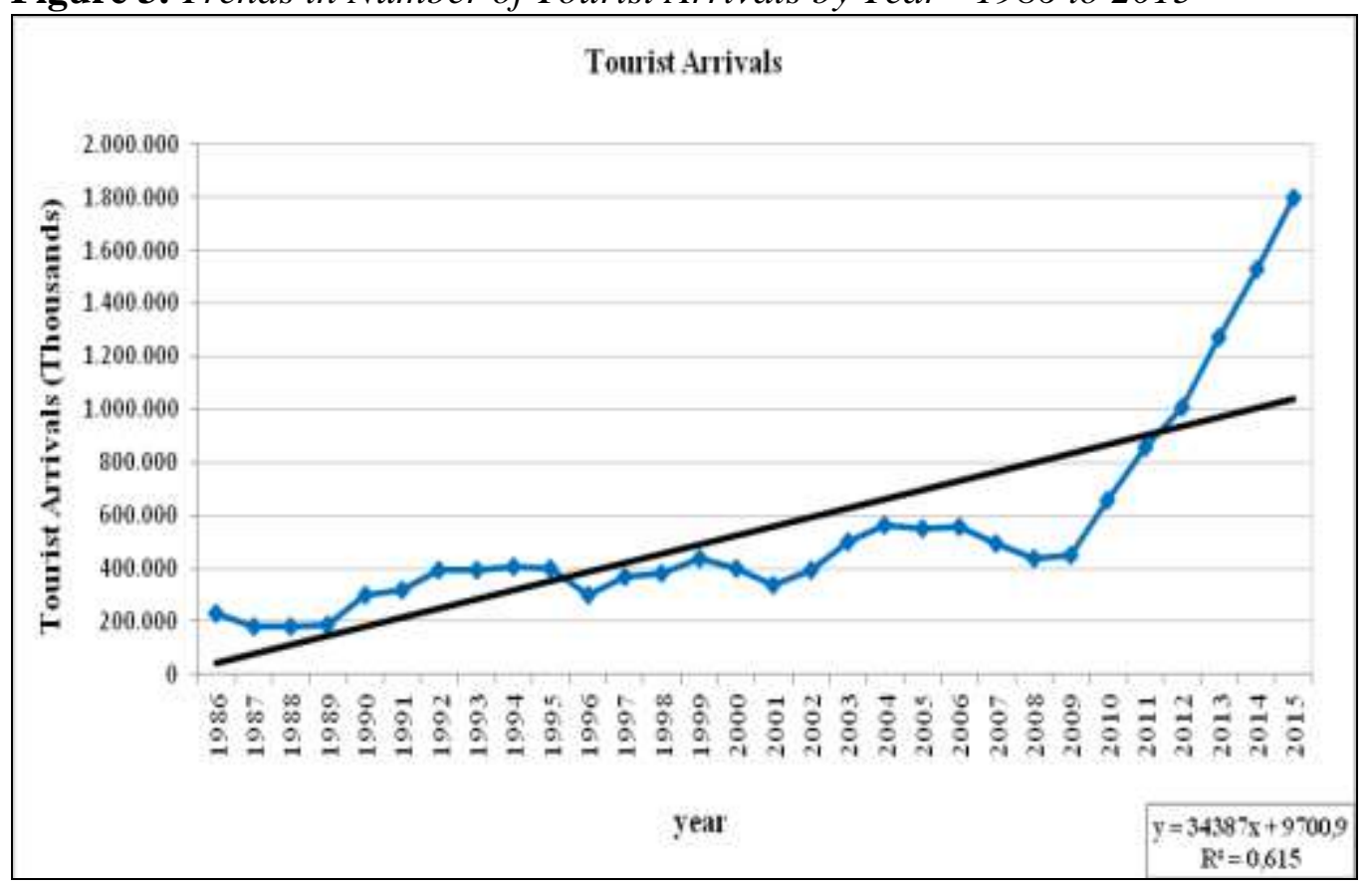

Source: Annual Statistical Report - 2015, SLTDA

Trends in the Percentage Distribution of Tourists by Profile Characteristics

$\underline{\text { Seasonality of Arrivals }}$

In statistical analysis, 12 months moving average method was used to examine the trends in the seasonal variations of tourist arrivals between 1986 and 2015. Monthly data regarding total number of tourist arrivals was obtained from the Annual Statistical Reports, which were published by the SLTDA for the analysis. The results of the 12-months moving average are given in Table 1 . 
Table 1. Seasonal Indices of tourist arrivals in Sri Lanka from 1986 to 2015

\begin{tabular}{|l|c|}
\hline \multicolumn{1}{|c|}{ Month } & Seasonal Indices of tourist arrivals \\
\hline January & 120 \\
\hline February & 115 \\
\hline March & 112 \\
\hline April & 89 \\
\hline May & 73 \\
\hline June & 76 \\
\hline July & 104 \\
\hline August & 102 \\
\hline September & 87 \\
\hline October & 93 \\
\hline November & 103 \\
\hline December & 125 \\
\hline
\end{tabular}

Source: Annual Statistical Report - 2015, SLTDA

Figure 4. Seasonality of Tourist Arrivals - 1986 to 2015

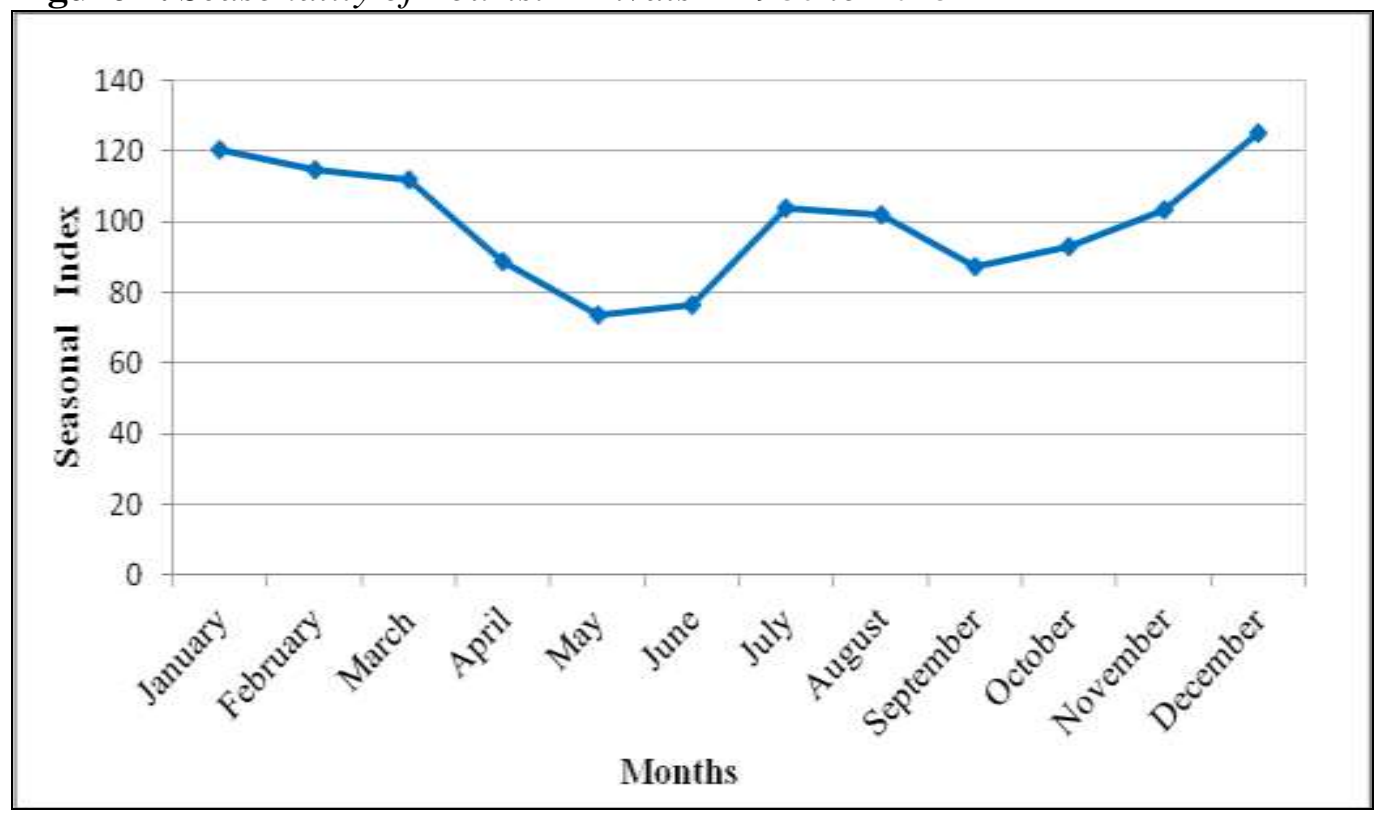

Source: Annual Statistical Report - 2015, SLTDA

The analysis has revealed that the seasonal indices of tourist arrivals in the country have been found to be ranging from 73 per cent to 125 per cent (Table 1). Figure 4 indicates the seasonal pattern of tourist arrivals in Sri Lanka. It is evident that the period from January to March and the month of December marks a peak season while July, August and November can be seen as mini peak months for tourist arrivals. The highest number of arrivals is recorded in December, with the Seasonal Index 125. The months of April, September and October can be marked as lean months of arrivals. The lowest number of arrivals are in the months of May and June. 


\section{Purpose of Visit}

In order to examine the trends in the percentage distribution of tourists by purpose of visit from 2001 to 2015, the annual percentage distribution of tourists was obtained from the Annual Statistical Reports, which were published by the SLTDA. According to the SLTDA (2013), the main motivations for travel to Sri Lanka were the purpose of pleasure/ holiday; visiting friends \&relations; religious \& cultural; convention \& meeting; business and other purposes. However, according to the SLTDA (2014), Department of Immigration and Emigration has been introduced a new system in 2013. The new system has a wide range of new categories as purpose of health, sports, education and official to declare information for the purpose of visit (SLTDA, 2014). Therefore, the data for the purpose of visit have been analyzed by using both the old and new categories. Linear Regression analysis was performed on the annual percentage distribution of tourists for each purpose of old category. Table 2 represents a summary of the regression analysis carried out for the purpose of visit Sri Lanka for the period of 2001 2015.

Table 2. Regression Parameters for Annual Percentage Distribution of Tourists by Purpose of Visit

\begin{tabular}{|c|c|c|c|c|c|}
\hline Purpose of Visit & $\begin{array}{c}\mathbf{m} \\
\text { (Slope) }\end{array}$ & $\begin{array}{c}c \\
\text { (Intercept) }\end{array}$ & $\begin{array}{c}\text { R- } \\
\text { square } \\
\left(\mathbf{R}^{2}\right)\end{array}$ & Trend & $\begin{array}{l}\text { Strength of } \\
\text { relationship }\end{array}$ \\
\hline $\begin{array}{l}\text { Visiting Friends \& } \\
\text { Relations }\end{array}$ & 1.2996 & -0.7671 & 0.6118 & Increase & Moderate \\
\hline Religious \& Cultural & 0.0088 & 1.4770 & 0.0010 & Increase & Low \\
\hline Others & $\begin{array}{c}- \\
0.0452\end{array}$ & 2.9944 & 0.0072 & Decrease & Low \\
\hline $\begin{array}{l}\text { Convention \& } \\
\text { meeting* }\end{array}$ & $\begin{array}{c}- \\
0.1535 \\
\end{array}$ & 3.0737 & 0.4477 & Decrease & Moderate \\
\hline Business & $\begin{array}{c}- \\
0.5390\end{array}$ & 13.354 & 0.2732 & Decrease & Low \\
\hline Pleasure/ Holiday & $\begin{array}{c}- \\
0.8939\end{array}$ & 82.608 & 0.3204 & Decrease & Low \\
\hline
\end{tabular}

Source: Prepared by the author based on the Regression results (2016)

Note: Data have been arranged in descending order based on the slope

*Data have been collected for the period of 2004 - 2015

According to Table 2, it is evident that all the purposes of visit, except two purposes, show a decreasing (negative) trend in the percentage distribution of tourists for the period of 2001 - 2015. Purpose of visiting friends \& relations, and purpose of religious \& cultural are the only purposes that have shown an increasing (positive) trend. It is noticeable that the trend of the tourists for the purpose of visiting friends and relations can be considered as a moderate increasing trend with a $\mathrm{R}^{2}$ value of 0.6118 . But it is noticeable that the trend can be considered as a significant one when compared with the purposes of 
religious \& cultural. During the period of 2004 - 2015, it is shown that the tourists for the purpose of Convention \& meeting has had a moderate decline in the percentage distribution. It is clear that out of the four purposes of visit, the purpose of pleasure/ holiday has recorded the lowest rate of decline of -0.8939 per cent per year (Table 2) in the percentage distribution of tourists by purpose of visit. It indicates that the tourists for the purpose of pleasure/ holiday has slightly less decreasing trend. It is also clear that the other purposes have recorded the highest rate of decline at the rate -0.0452 per cent per year but it is not a statistically significant relationship as the $\mathrm{R}^{2}$ value for about 0.0072 . Figure 5 shows the linear trends in percentage distribution of tourists by purpose of visit in years from 2001 to 2015. This graphical representation clearly shows that some purposes of visit have high variability in the recorded percentage distribution of tourists. According to Figure 5, it is interesting to note that all the new categories for the purpose of visit seem the increasing trend from 2014 to 2015. Among the new categories of purpose of visit Sri Lanka, there is a significant rise in the percentage of tourists for the purpose of health. It is also clear that from 2014 to 2015, the percentage of tourists for the purpose of health increased rapidly.

Figure 5. Trends in Percentage Distribution of Tourists by Purpose of Visit 2001 to 2015

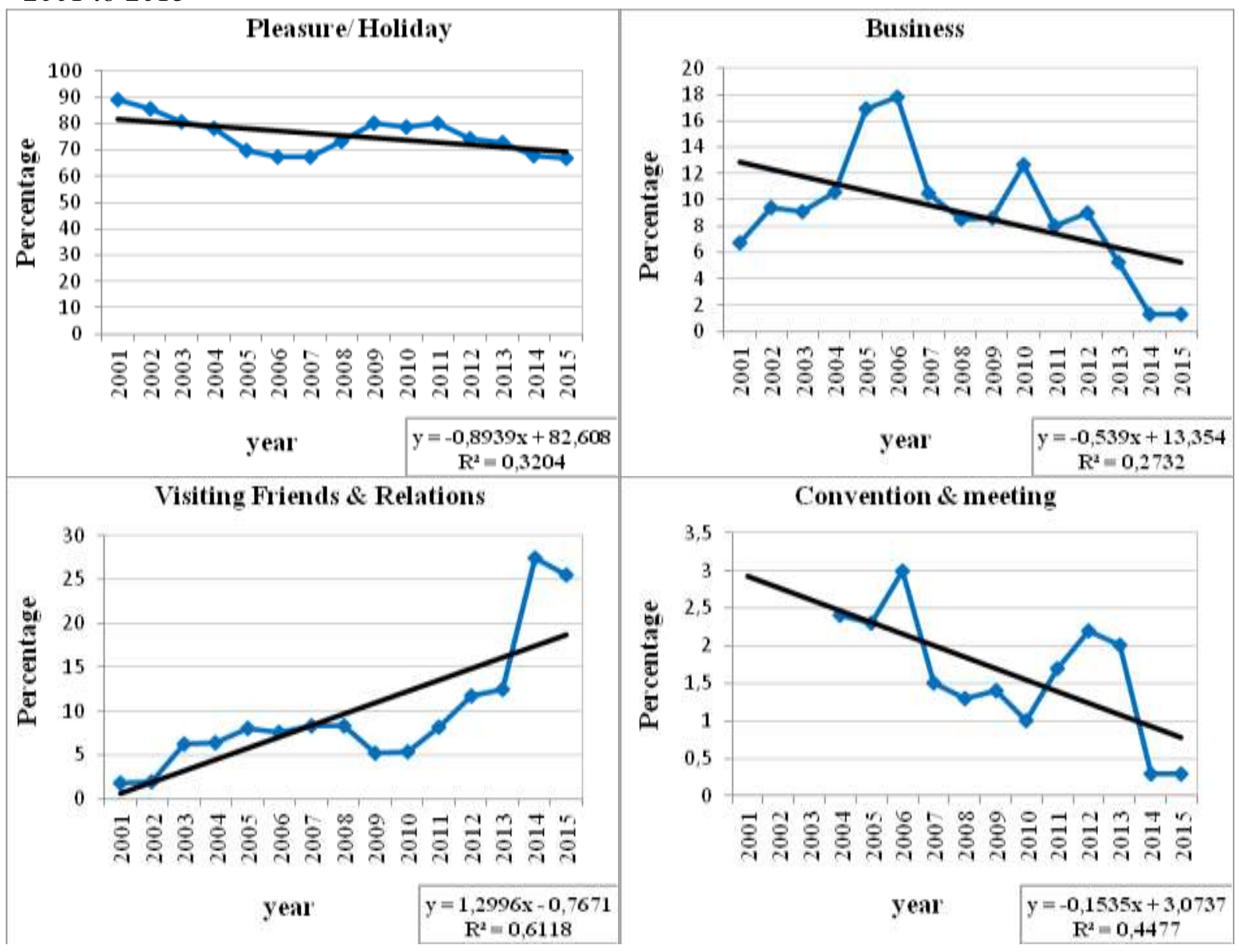



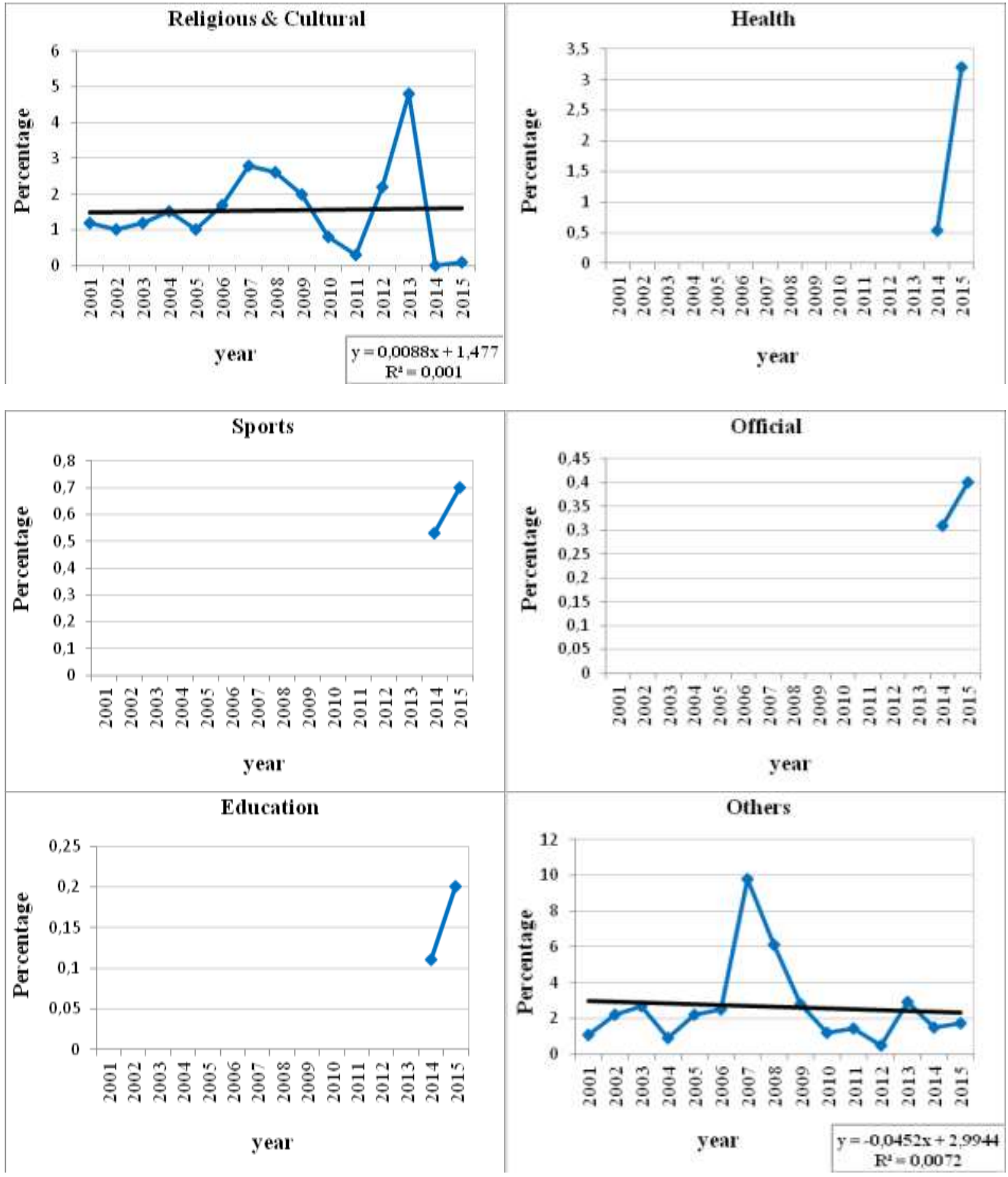

Source: Annual Statistical Report - 2010 \& 2015, SLTDA

\section{Period of Stay}

Not only the arrivals of tourists, but also the length of their stay in the country is also important. Accordingly, in statistical analysis, utilizing 15 years of tourist's records in wide range categories of period of stay, Regression Analysis was carried out to extract the trends in annual percentage for each 
period of stay of tourists between 2001 and 2015. Figure 6 indicates the linear trends in percentage distribution of tourists by period of stay for the period of 2001 - 2015. Table 3 represents a summary of the Regression Analysis carried out for the period of stay in Sri Lanka for the period of $2001-2015$.

Figure 6. Trends in Percentage Distribution of Tourists by Period of Stay - 2001 to 2015

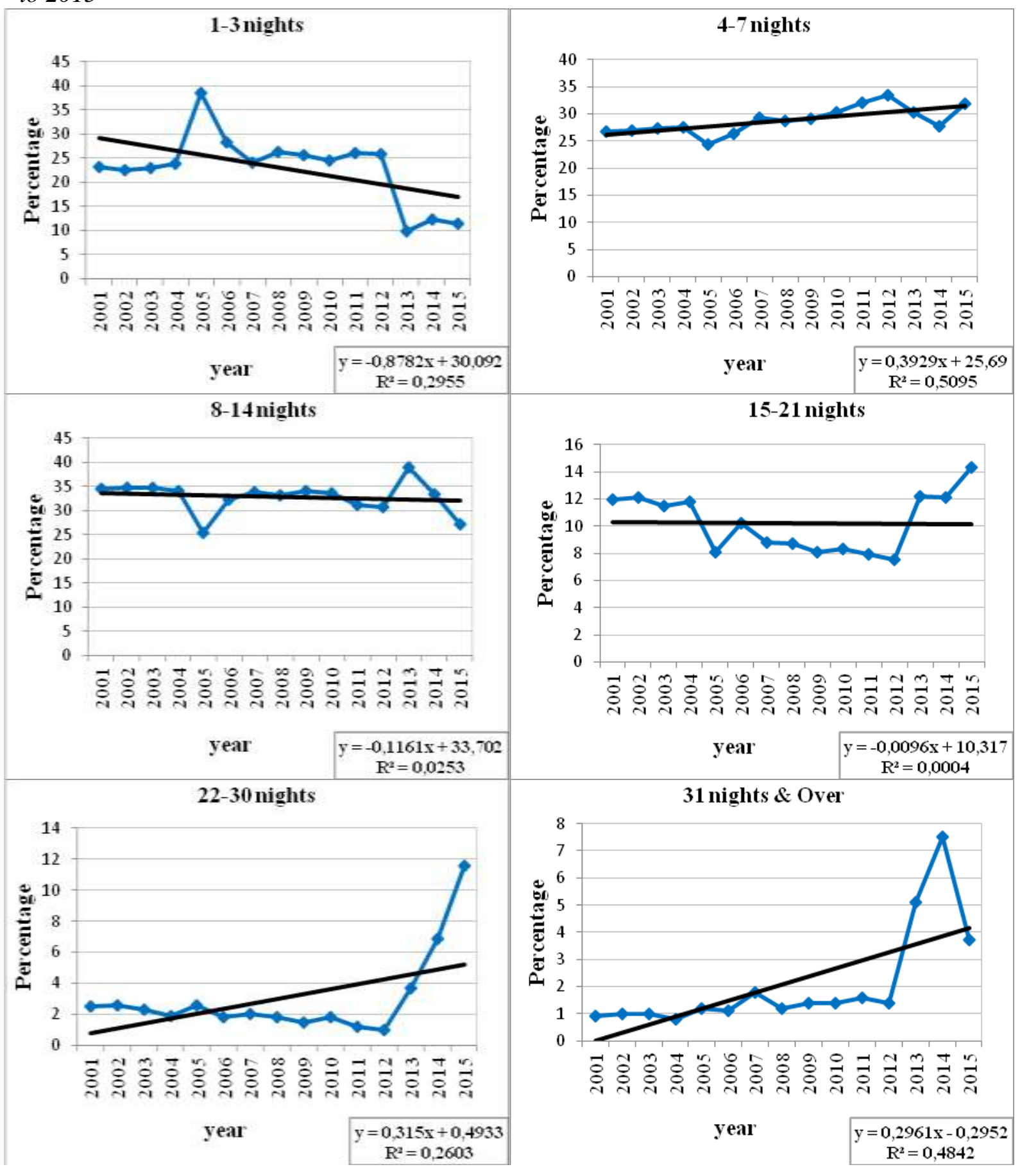

Source: Annual Statistical Report - 2015, SLTDA 
The trend analyses show that the statistically increasing trends have been recorded in tourist nights of between 4-7 nights, 22-30 nights, and 31 nights \& over with rates of 0.3929 per cent per year, 0.3150 per cent per year and 0.2961 per cent per year respectively. Statistically decreasing trends have been recorded in tourist nights of between 15-21 nights, 8-14 nights and 1-3 nights with rates of -0.0096 per cent per year, -0.1161 per cent per year and -0.8782 per cent per year respectively (Table 3). It is revealed that the durations of between 4-7 nights, and 31 nights \& over have depicted a moderate positive trend in all the nights spent by the tourists who visited the country for the period of $2001-2015$. On the other hand, the overall trend shows that the period of stay between 1-3 nights has a significantly lower rate of decline in the percentage distribution of tourists by period of stay throughout the period. But according to the graphical representation (Figure 6) it indicates that a significant decreasing trend.

Table 3. Regression Parameters for Annual Percentage Distribution of Tourists by Period of Stay

\begin{tabular}{|l|c|c|c|c|c|}
\hline \multicolumn{1}{|c|}{ Period of stay } & $\begin{array}{c}\mathbf{m} \\
(\text { Slope })\end{array}$ & $\begin{array}{c}\mathbf{c} \\
(\text { Intercept })\end{array}$ & $\begin{array}{c}\text { R- } \\
\text { square } \\
\left(\mathbf{R}^{\mathbf{2}}\right)\end{array}$ & Trend & $\begin{array}{c}\text { Strength of } \\
\text { relationship }\end{array}$ \\
\hline $4-7$ nights & 0.3929 & 25.6900 & 0.5095 & Increase & Moderate \\
\hline $22-30$ nights & 0.3150 & 0.4933 & 0.2603 & Increase & Low \\
\hline 31 nights \& over & 0.2961 & -0.2952 & 0.4842 & Increase & Moderate \\
\hline $15-21$ nights & - & 10.3170 & 0.0004 & Decrease & Low \\
\hline $8-14$ nights & - & 33.7020 & 0.0253 & Decrease & Low \\
\hline $1-3$ nights & - & 30.0920 & 0.2955 & Decrease & Low \\
\hline
\end{tabular}

Source: Prepared by the author based on the Regression results (2016)

Note: Data have been arranged in descending order based on the slope

\section{$\underline{\text { Age \& Sex Distributions }}$}

The Figure 7 shows that the trends in percentage distribution of tourists by Age groups between 2001 and 2015. When considering the Age Composition of tourists, the annual percentage of tourist arrivals has increased in all age groups except in the age groups of between 30-39 years and between 20-29 years (Table 4). For which the regression parameters record the decreases of 0.8129 per cent per year and -0.9446 per cent per year respectively, which are only significant decreases as can be noted from Figure 7. It is evident that the lowest rate of decline in the annual percentage of tourist arrivals by age groups has demonstrated the tourists in between 20-29 years, with rate of -0.9446 per cent per year. It is shown that the trend of tourists were between 20-29 years has had a moderate decline. 
Vol. 4, No. 1 Perera: An Analysis of Recent Trends in Tourist Arrivals in Sri Lanka

Figure 7. Trends in Percentage Distribution of Tourists by Age Groups - 2001 to 2015

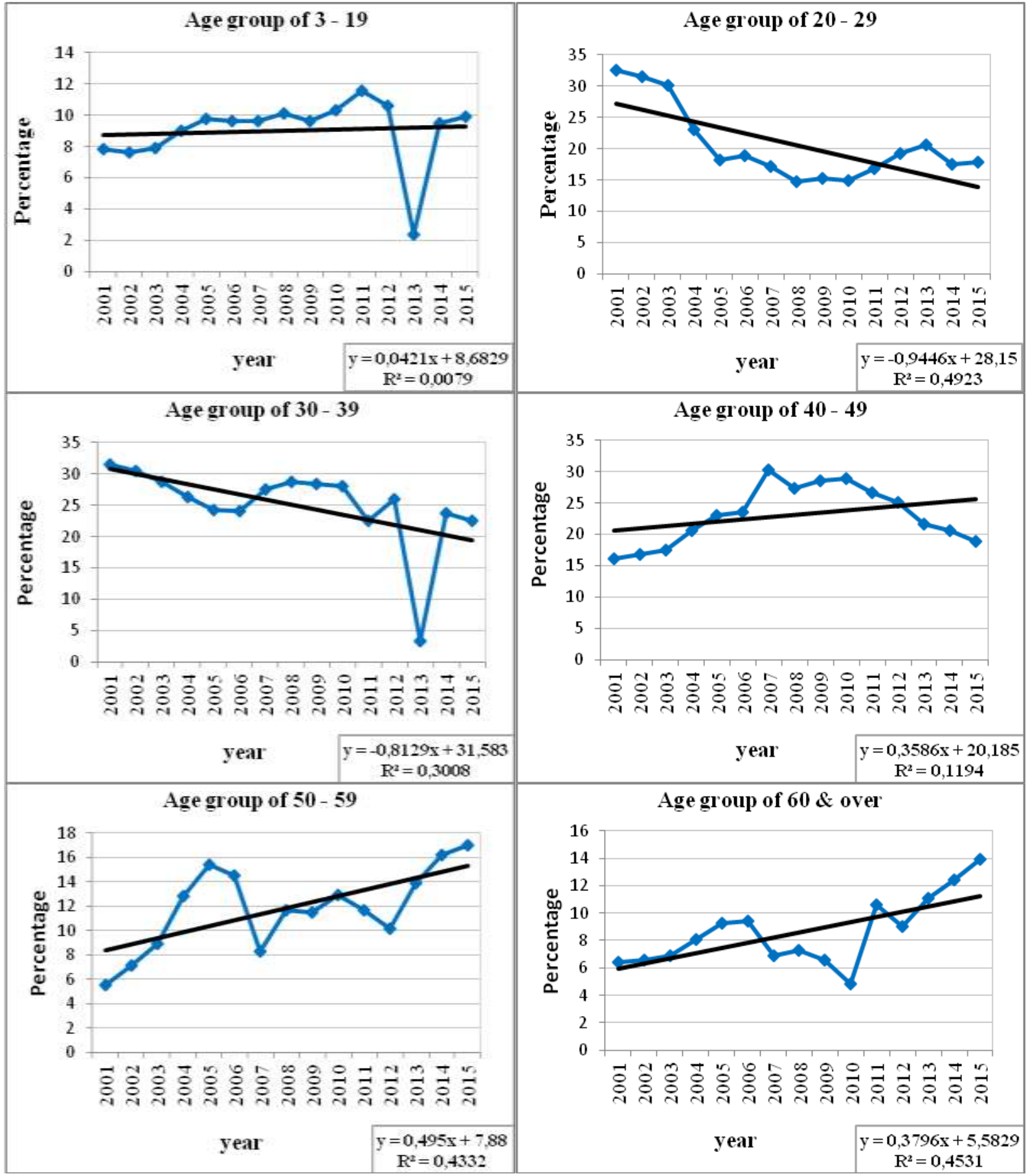

Source: Annual Statistical Report - 2010 \& 2015, SLTDA 
Table 4. Regression Parameters for Annual Percentage Distribution of Tourists by Age Groups

\begin{tabular}{|l|c|c|c|c|c|}
\hline $\begin{array}{c}\text { Age } \\
\text { Groups }\end{array}$ & $\begin{array}{c}\mathbf{m} \\
\text { (Slope) }\end{array}$ & $\begin{array}{c}\mathbf{c} \\
\text { (Intercept) }\end{array}$ & $\begin{array}{c}\text { R-square } \\
\left(\mathbf{R}^{\mathbf{2}}\right)\end{array}$ & Trend & $\begin{array}{c}\text { Strength of } \\
\text { relationship }\end{array}$ \\
\hline $50-59$ & 0.4950 & 7.8800 & 0.4332 & Increase & Moderate \\
\hline $60 \&$ over & 0.3796 & 5.5829 & 0.4531 & Increase & Moderate \\
\hline $40-49$ & 0.3586 & 20.1850 & 0.1194 & Increase & Low \\
\hline $3-19$ & 0.0421 & 8.6829 & 0.0079 & Increase & Low \\
\hline $30-39$ & -0.8129 & 31.5830 & 0.3008 & Decrease & Low \\
\hline $20-29$ & -0.9446 & 28.1500 & 0.4923 & Decrease & Moderate \\
\hline
\end{tabular}

Source: Prepared by the author based on the Regression results (2016)

Note: Data have been arranged in descending order based on the slope

On the other hand, the above tabulation clearly shows that the highest rate of increasing trend in annual percentage is shown in the age group of between 50 to 59 , with a rate of 0.4950 per cent per year while the lowest rate of increasing trend is represented in the age group between 3 to 19, with a rate of 0.0421 per cent per year, which is only a slight increase as can be noted from Figure 7. According to the results revealed from the study, the overall picture shows that the tourists, especially younger tourists have demonstrated a decreasing trend and older tourists have demonstrated an increasing trend to visit Sri Lanka during the period of 2001-2015.

When considering the gender of tourists, according to Table 5, it is revealed that the trends in percentage distribution of female and male representation are respectively positive and negative in the years between 2001 and 2015. However, these trends are not very significant relationship as the $\mathrm{R}^{2}$ accounts for about 0.2031 (Table 5). The most significant fact is that the increasing and decreasing trends are recorded according to the gender of tourists with the same rate of 0.2961 per cent per year. These factors can be clearly displayed in graphical form (See Figure 8).

Table 5. Regression Parameters for Annual Percentage Distribution of Tourists by Sex

\begin{tabular}{|l|c|c|c|c|c|}
\hline \multicolumn{1}{|c|}{ Gender } & $\begin{array}{c}\mathbf{m} \\
\text { (Slope) }\end{array}$ & $\begin{array}{c}\mathbf{c} \\
(\text { Intercept })\end{array}$ & $\begin{array}{c}\mathbf{R}- \\
\mathbf{s q u a r e} \\
\left(\mathbf{R}^{2}\right)\end{array}$ & Trend & $\begin{array}{c}\text { Strength of } \\
\text { relationship }\end{array}$ \\
\hline Female & 0.2961 & 38.9110 & 0.2031 & Increase & Low \\
\hline Male & - & 61.0890 & 0.2031 & Decrease & Low \\
\hline
\end{tabular}

Source: Prepared by the author based on the Regression results (2016)

Note: Data have been arranged in descending order based on the slope 
Figure 8. Trends in Percentage Distribution of Tourists by Sex - 2001 to 2015
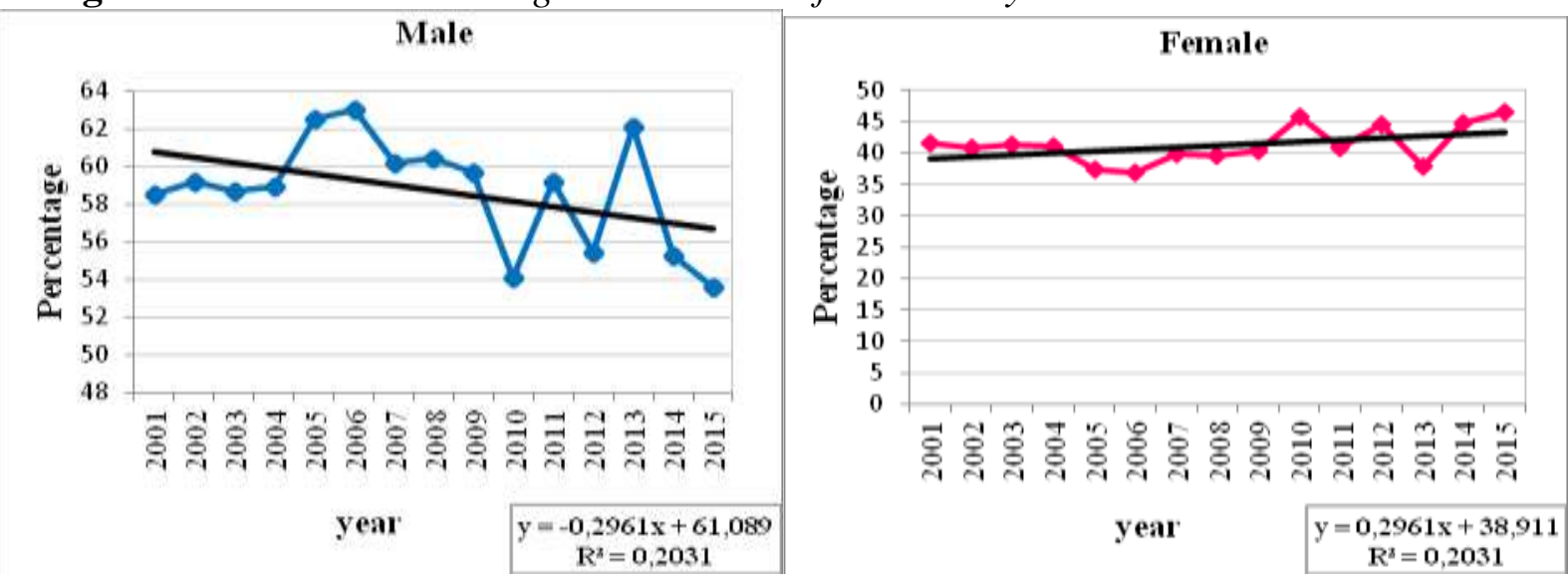

Source: Annual Statistical Report - 2010 \& 2015, SLTDA

\section{Occupation}

The trend analyses show that all the occupational categories, except three occupational categories (Executives, No Occupation and Other Occupation) have an increasing trend in annual percentage distribution of the tourist who arrived in Sri Lanka during the period from 2001 to 2015 (Table 6). The categories of "No occupation" and "Other occupation" have a strong decrease in the annual percentage of tourist arrivals and it is noticeable that the trend can be considered as a moderate one as the $\mathrm{R}^{2}$ values are 0.5877 and 0.6278 respectively while "Executives" have shown a low decline during the study period. It is also shown that the occupational category of "Professionals" has had a moderately strong positive trend with rate of 0.8775 per cent per year. Businessmen and Educationists have shown a moderate increasing trend with rate of 0.7021 and 0.2725 per cent per year respectively. According to the facts revealed from the statistical analysis, it is noticeable that the majority of the tourists who arrived in Sri Lanka during the period were gainfully occupied which have shown a significant increasing trend in annual percentage distribution of tourists. However, the occupational category of the "Scientists $\&$ Technicians" has a slightly increasing trend. It is displayed in Figure 9.

Table 6. Regression Parameters for Annual Percentage Distribution of Tourists by Occupational Categories

\begin{tabular}{|l|c|c|c|c|c|}
\hline Occupation & $\begin{array}{c}\text { m } \\
\text { (Slope) }\end{array}$ & $\begin{array}{c}\text { c } \\
\text { (Intercept) }\end{array}$ & $\begin{array}{c}\text { R-square } \\
\left(\mathbf{R}^{\mathbf{2}}\right)\end{array}$ & Trend & $\begin{array}{c}\text { Strength of } \\
\text { relationship }\end{array}$ \\
\hline Professionals & 0.8775 & 3.9867 & 0.6251 & Increase & Moderate \\
\hline Businessmen & 0.7021 & 9.2895 & 0.4258 & Increase & Moderate \\
\hline Educationists & 0.2725 & 4.5533 & 0.4341 & Increase & Moderate \\
\hline Retired persons & 0.1268 & 4.9657 & 0.1636 & Increase & Low \\
\hline Scientists \& Technicians & 0.0307 & 7.4476 & 0.0243 & Increase & Low \\
\hline Executives & -0.4457 & 17.4320 & 0.3932 & Decrease & Low \\
\hline No Occupation & -0.6046 & 21.6900 & 0.5877 & Decrease & Moderate \\
\hline Other Occupation & -0.9593 & 30.6340 & 0.6278 & Decrease & Moderate \\
\hline
\end{tabular}

Source: Prepared by the author based on the Regression results (2016)

Note: Data have been arranged in descending order based on the slope 
Figure 9. Trends in Percentage Distribution of Tourists by Occupational Categories - 2001 to 2015

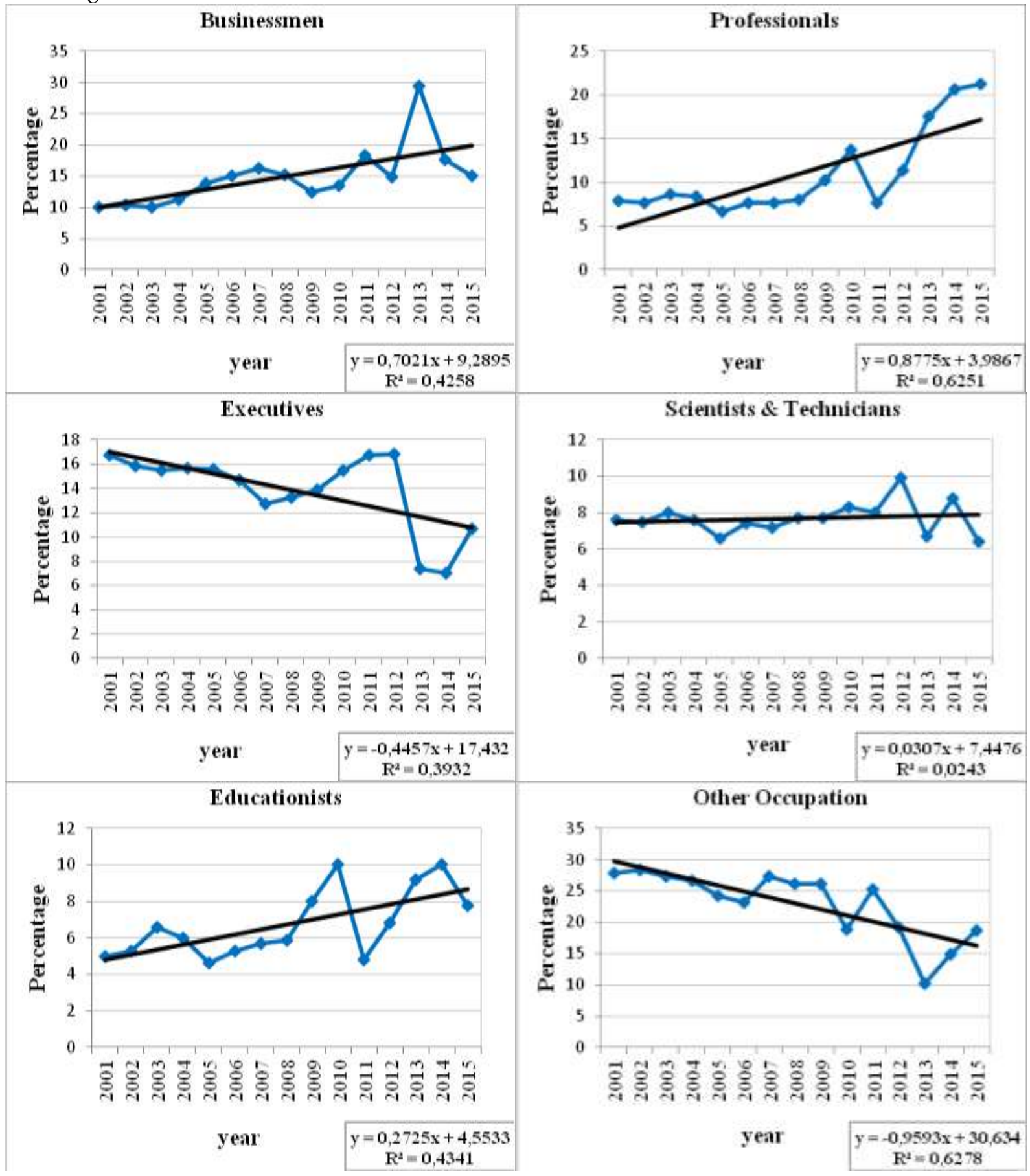



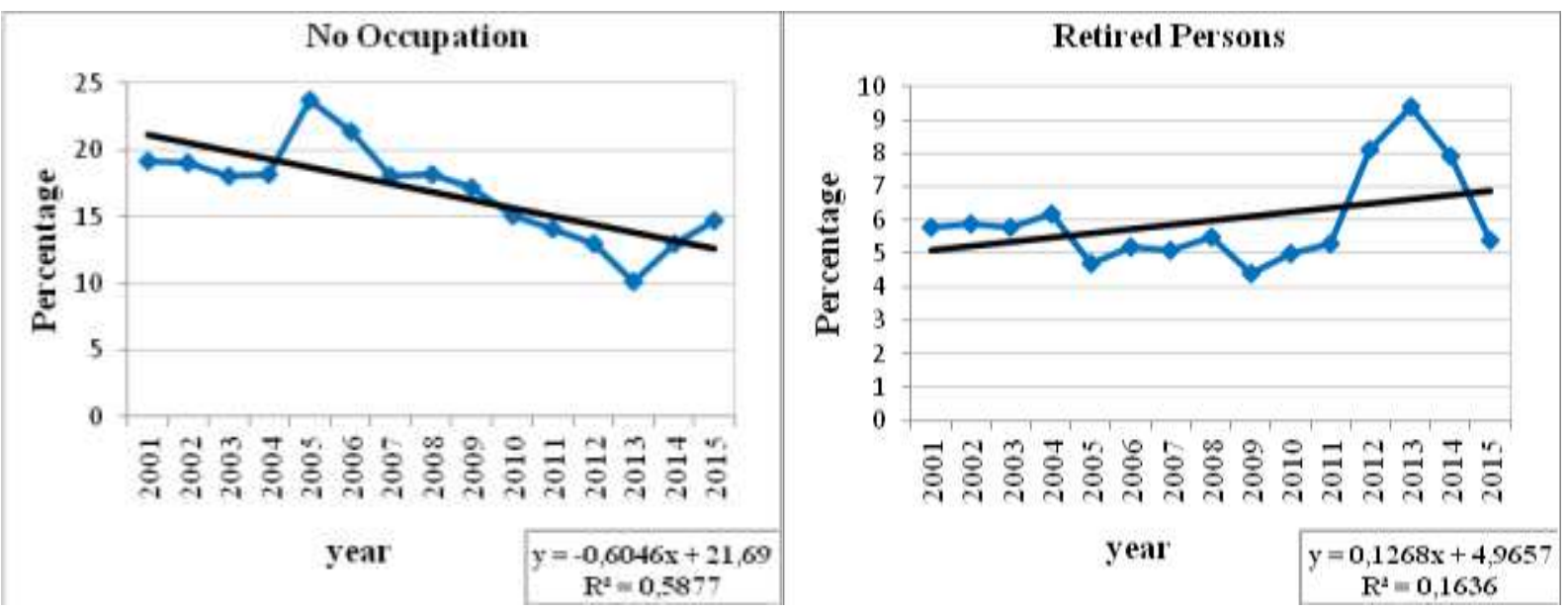

Source: Annual Statistical Report - 2010 \& 2015, SLTDA

\section{Trends in Annual Tourist Arrivals by Different Regions}

In order to analyze trends in the annual tourist arrivals by different regions, the annual total number of tourist arrivals were obtained from the Annual Statistical Reports, which were published by the SLTDA. Linear Regression analysis was performed on the annual number of tourist arrivals for each region. Table 7 represents a summary of the regression analysis carried out for the nine regions for the period of $2001-2015$.

Table 7. Regression Parameters for Annual Tourist Arrivals by Deferent Regions

\begin{tabular}{|l|c|c|c|c|c|}
\hline \multicolumn{1}{|c|}{ Region } & $\begin{array}{c}\mathbf{m} \\
\text { (Slope) }\end{array}$ & $\begin{array}{c}\mathbf{c} \\
(\text { Intercept })\end{array}$ & $\begin{array}{c}\text { R- } \\
\text { square } \\
\left(\mathbf{R}^{\mathbf{2}}\right)\end{array}$ & Trend & $\begin{array}{c}\text { Strength of } \\
\text { relationship }\end{array}$ \\
\hline South Asia & 22392 & 16664 & 0.7913 & Increase & Remarkable \\
\hline Western Europe & 19971 & 128826 & 0.5775 & Increase & Moderate \\
\hline East Asia & 16437 & -22981 & 0.5899 & Increase & Moderate \\
\hline Eastern Europe & 10132 & -32362 & 0.7585 & Increase & Remarkable \\
\hline Middle East & 6862.3 & -19851 & 0.8490 & Increase & Remarkable \\
\hline Australasia & 3979.2 & 4220.1 & 0.8427 & Increase & Remarkable \\
\hline North America & 3673.9 & 7720.4 & 0.4188 & Increase & Moderate \\
\hline Africa & 681.99 & -1289.5 & 0.6375 & Increase & Moderate \\
\hline Latin America & 229.8 & -14.629 & 0.4194 & Increase & Moderate \\
\hline Soun
\end{tabular}

Source: Prepared by the author based on the Regression results (2016)

Note: Data have been arranged in descending order based on the slope 
Figure 10. Trends in Tourist Arrivals by Regions - 2001 to 2015

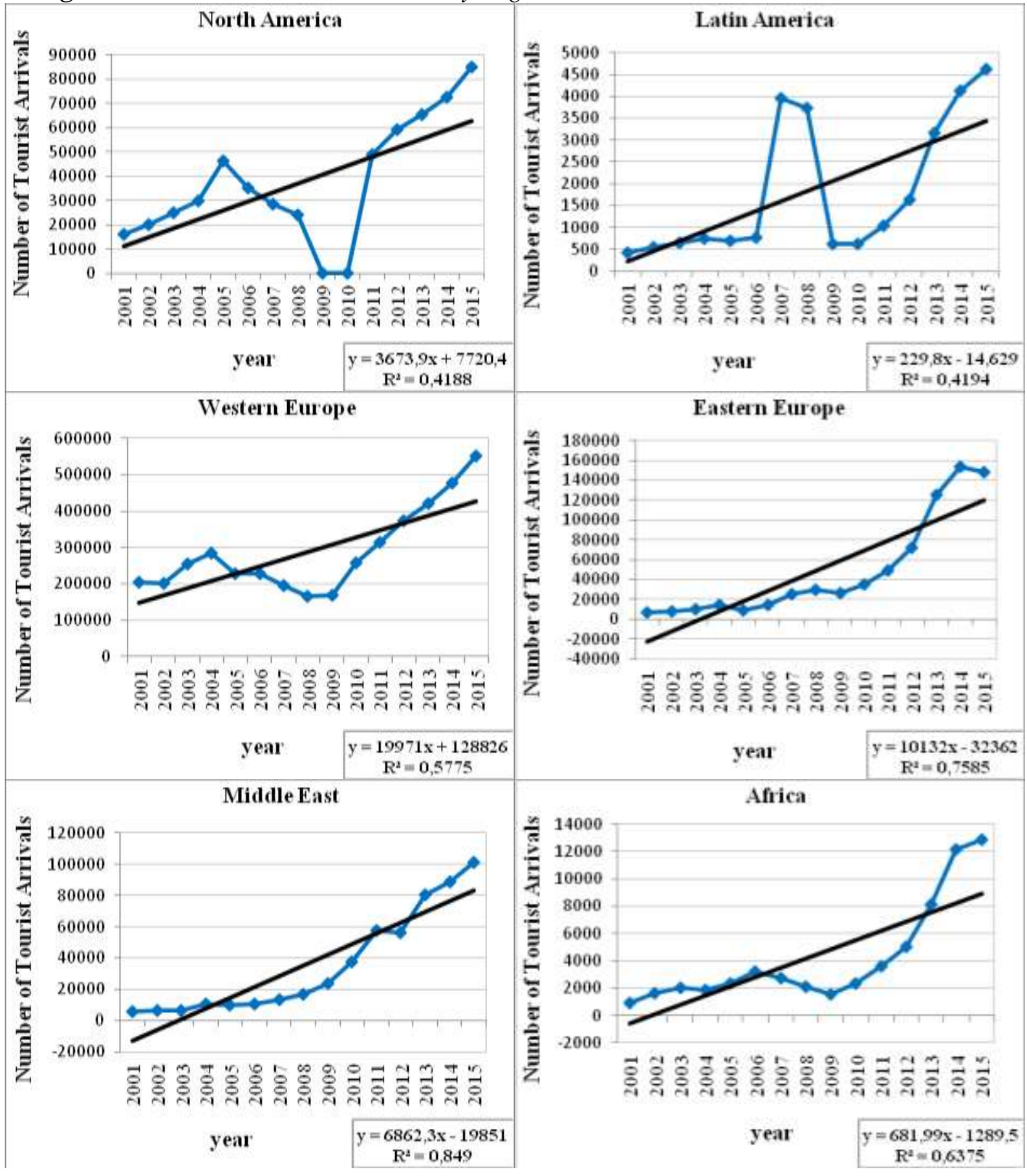




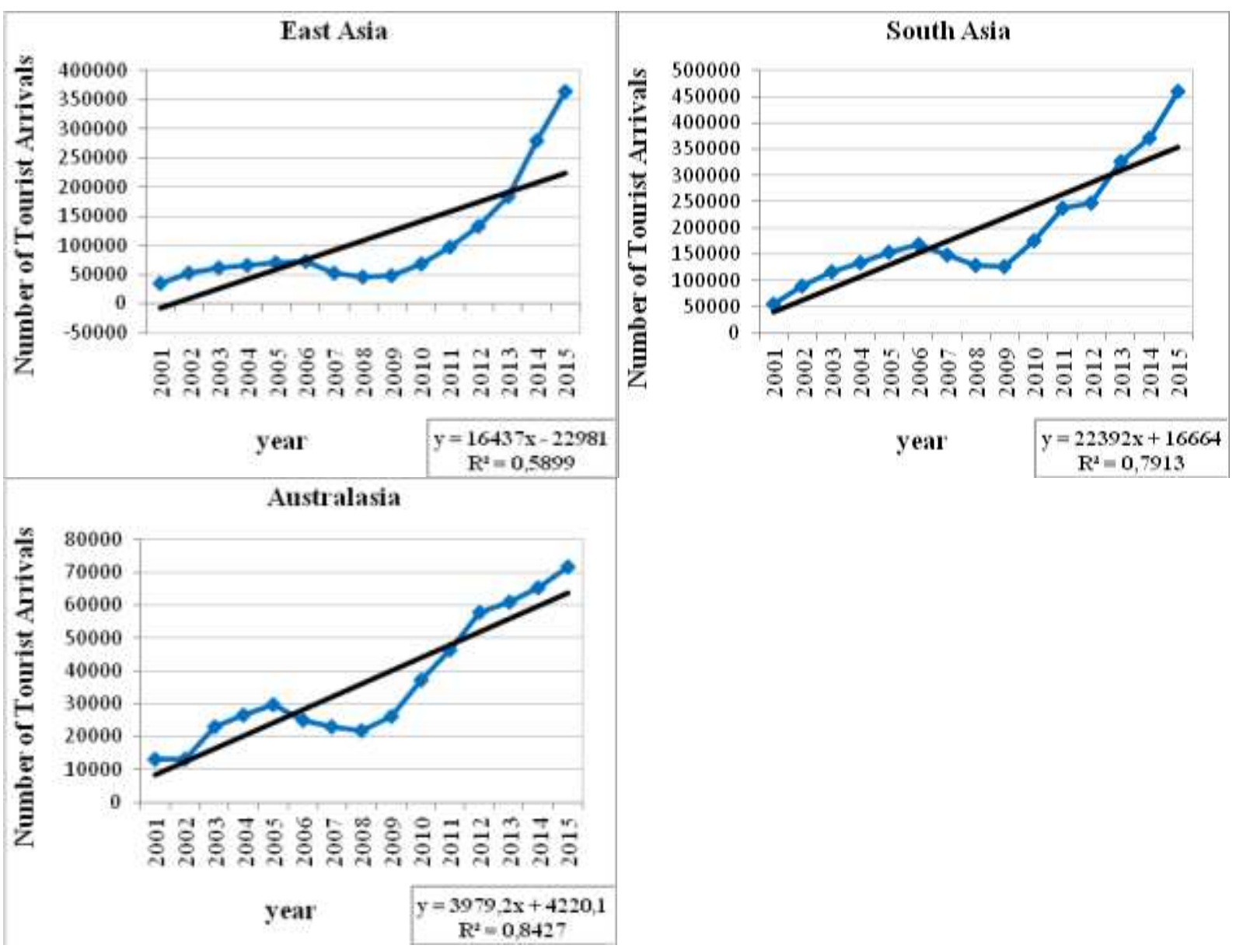

Source: Annual Statistical Report - 2005, 2010 \& 2015, SLTDA

When considering the Regional Distribution of tourist arrivals, it is observable that all the regions have an increasing trend in annual number of tourist arrivals (Table 7). At the regional level, it is also clear that all the regions except five regions have represented a remarkable increase for the period of 2001-2015. Tourists who come to Sri Lanka from the South Asian region has shown the highest annual growth with a rate of 22392 arrivals per year. An arguable reason for this result is the peaceful environment of Sri Lanka due to end of the war. It is also revealed by the results of the current study that the significant increasing trend of the tourists for the purpose of visiting friends and relations. Therefore, tourist arrivals from the South Asian regions have been generated the majority of Sri Lankan tourism.

After that, it is noteworthy that tourists who come to Sri Lanka from the Western Europe and the East Asia have shown a higher growth of their arrivals with rate of 19971 and 16437 arrivals per year respectively. However, it is noticeable that the trend can be considered as a moderate one. According to the results of the study, a significant seasonal effect is evident in data of tourist arrivals in Sri Lanka. An arguable reason for these results is the seasonal variations in those countries that generate the majority of Sri Lankan tourism, mainly European countries in the Northern Hemisphere. Although, according 
to the annual data, tourist arrivals from European countries have been decreased during the final years of the war from 2006 to 2009 due to some European countries recognized Sri Lanka as an unsafe tourist destination and prohibited their tourists to visit Sri Lanka during that time.

By regions, the lowest number of arrivals that observed an increasing trend is recorded in the Latin America with a rate of 230 arrivals per year. A moderately slight positive trend has been observed in the case of tourist arrivals from the North America and the Latin America. Figure 10 also clearly shows that some regions have high variability in the recorded number of tourist arrivals, mainly North America and Latin America. The results also reveal that there is a significant increase of tourist arrivals from all the regions after the year 2009.

\section{Conclusion}

The study found that the overall trend in the total number of tourist arrivals in Sri Lanka has shown a moderate increasing trend throughout the previous three decadal periods from 1986 to 2015. According to the previous study conducted by Ismail, Velnampy and Mustafa (2012), the results indicated that the number of tourist arrivals have increased from 2000 to 2011 and forecasted number of tourist arrivals during 2011 to 2015 would be a positive sign for the growth of tourism industry in Sri Lanka. Angappapillai and Shanmugasundram (2013) also stated that the trend co-efficient of foreign tourist arrivals is positive in India. However, the trend co-efficient is not statistically significant.

Secondly, the study was evident that the period from January to March and the month of December marked as a peak seasons while July, August and November can be seen as mini peak months for tourist arrivals. The highest number of arrivals is recorded in December, with the Seasonal Index 125. The months of April, September and October can be marked as lean months of arrivals. The lowest number of arrivals are in the months of May and June. It was observed that the period from April to June marks a lean period of foreign tourist arrivals in the Thanjavur region. The peak season for arrivals has been found to be August to December (Angappapillai and Shanmugasundram, 2013). When compared with the similar study conducted by Fernando et al. (2013) in Sri Lanka, the results showed that the Significant seasonal dummy variables with negative coefficients for April, May, and September. Peak levels of tourist arrivals are observed in November to January. The authors stated that the arguable reason for this result is the seasonal variations in those countries that generate the majority of Sri Lankan tourism, mainly European countries in the Northern Hemisphere. Their winter weather begins in November and ends in March, the same times in which Asian countries attract more tourists from Northern Hemisphere countries. The authors also stated that this will apply to Sri Lanka too and, therefore, months from November to March can be considered as peak months with positive impacts in terms of tourist arrivals to Sri Lanka. There is a decline in tourist arrivals in some months such as April, 
May and September, as Sri Lanka is not attractive to Northern Hemisphere visitors, perhaps due to rainy weather conditions in the southern part of the country. Therefore, it can be recommended that the country promote the eastern and northern parts of the country during those months and attract tourists from nontraditional sources like Australia and Southeast Asian countries. Further, this requires a better understanding of seasonality to enhance the operational decisions, such as capacity planning and development in many related area and planning the human resource for the peak demand periods (Kurukulasooriya and Lelwala, 2014).

It is also evident that all the purposes of visit, except two purposes, show a decreasing trend in the percentage distribution of tourists for the period of 2001 - 2015. Purpose of visiting friends \& relations, and purpose of religious \& cultural are the only purposes that have shown an increasing trend. The trend of the tourists for the purpose of visiting friends and relations has had a significant increasing trend with a $\mathrm{R}^{2}$ value of 0.6118 . It is clear that out of the four purposes of visit, the purpose of pleasure/ holiday has slightly less decreasing trend. However, according to the study conducted by Dhakal (2013) in Nepal, most of the tourists came for holiday/pleasure purpose followed by religious purposes and trekking and mountaineering. It indicates that there is a need to develop many opportunities for winning the tourist attraction and build a better infrastructure.

The durations between 4-7 nights and 31 nights \& over have depicted a moderate positive trend in all the nights spent by the tourists who visited the country. This could indicate that the overall picture showed that the tourists, especially younger tourists have demonstrated a decreasing trend and older tourists have demonstrated an increasing trend to visit Sri Lanka during the study period. Therefore, it should be promote many sports and adventure activities for young tourist. The study revealed that the trends in percentage distribution of female and male representation were respectively positive and negative. It indicates that there is a need to develop appropriate situation to attract the male visitors in Sri Lanka. The majority of the tourists who arrived in Sri Lanka during the period were gainfully occupied which have shown a significant increasing trend in annual percentage distribution of tourists. Finally, at the regional level, tourist arrivals from South Asia, Eastern Europe, Middle East and Australasia regions have shown a remarkable increase. Therefore, the tourism authorities in Sri Lanka need to implement marketing strategies to attract tourists among non-traditional regions. The findings of this study can be used by authorities of tourism in Sri Lanka to produce a better tourism plan for the development of the industry.

\section{References}

Adventure Sports in Sri Lanka (2016) Available at: http://www.lankawalker.com/ adventure-sports.html, (Accessed: 22 November 2016). 
Agarwal, N. (2015) "An Analytical study of tourist perception for accommodation sector in reference to Dehradun and Mussoorie", International Journal of Arts, Humanities and management Studies, 1(6), pp. 8-19.

Angappapillai, A.B. and Shanmugasundram, N. (2013) "Trends in Tourist Arrivals and the impact on Hotel Accommodation in Thanjavur District", Asia Pacific Journal of Marketing \& Management Review, 2 (8), pp. 41-50.

Bhatia, A.K. (2006) The Business of Tourism: Concepts and Strategies, New Delhi: Sterling publishers (Pvt) Ltd.

Central Bank of Sri Lanka (2014) Annual Report, Colombo: Central Bank of Sri Lanka.

Central Bank of Sri Lanka (2015) Annual Report, Colombo: Central Bank of Sri Lanka.

De Silva, W.G. (2016) A Mosaic of Culture and Nature. Available at: http://www.jet wingeco.com/articles/mosaic-culture-nature/ (Accessed 15 September 2016).

Department of Census and Statistics (2015) Statistical Abstract - Chapter Xvii Tourism. Available at: http://www.statistics.gov.lk/Abstract2015/index.asp?Page =chap17 (Accessed: 21 October 2016).

Department of Meteorology (2015) Climate in Sri Lanka. Available at: $\mathrm{http}: / / \mathrm{www} . \mathrm{meteo.gov} . \mathrm{k} / \mathrm{index}$. php?option=com_content $\&$ view $=$ article $\& \mathrm{id}=13 \&$ Itemid=132\&lang=en\#1-first-inter-monsoon-season-march-april (Accessed: 20 April 2015).

Educational Publications Department (2015) Grade 6 Geography, Isurupaya: Educational Publications Department.

Fernando, S.L.J. and Shariff, N.M. (2013) Trends, Environmental Issues and Challenges of Ecotourism in Sri Lanka, Bangkok: IBEA.

Goeldner, C.R. \& Ritchie, J.R.B. (2009) Tourism: Principles, Practices, Philosophies, New York City: John Wiley \& Sons. Available at: http://shora.tabriz.ir/Uploads/ 83/cms/user/File/657/E_Book/Tourism/Tourism\%20Principles\%20Practices\%20 Philosophies\%2011th\%20ed\%202009.pdf (Accessed: 12 August 2016).

ICRA Lanka and IMACS (2011) Industry Report on Sri Lanka, Colombo 01: ICRA Lanka Ltd.

Jayapalan, N. (2001) An Introduction to Tourism, New Delhi: Atlantic Publishers and Distributors.

Lai, T.W. (2002) "Promoting Sustainable Tourism in Sri Lanka", in Hundloe, T. (ed.) Linking Green Productivity to Ecotourism: Experiences in the Asia-Pacific Region. Tokyo: Asian Productivity Organization, pp. 208-214.

Ministry of Economic Development (2010) Tourism Development Strategy (2011 2016), Colombo: Ministry of Economic Development.

Neto, F. (2003) "A New Approach to Sustainable Tourism Development: Moving Beyond Environmental Protection", DESA Discussion Paper No. 29, pp. 1-11. Available at: http://www.un.org/esa/esa03dp29.pdf (Accessed 22 November 2016).

Ranasinghe, R. (2015) "Strategic myopia of tourism development in Sri Lanka: A critique", International Journal of Multidisciplinary Research and Development, 2(2), pp. 604-609.

Ranasinghe, R. and Deyshappriya, R. (2010) "Analyzing the Significance of Tourism on Sri Lankan Economy; An Econometric Analysis", ICBI, Dalugama: University of Kelaniya, pp. 1-19.

Research \& International Relations Division (2005) Annual Statistical Report, Colombo 03: Sri Lanka Tourist Board. Available at: https://www.scribd.com/ fullscreen/36052112?access_key=key-10d3u70vvvpxy3ncgxnw, (Accessed: 09 July 2016). 
Research \& International Relations Division (2008) Annual Statistical Report, Colombo 03: Sri Lanka Tourism Development Authority. Available at: https:// www.scribd.com/document/19291297/Annual-Report-2008, (Accessed: 09 July 2016).

Research \& International Relations Division (2010) Annual Statistical Report, Colombo 03: Sri Lanka Tourism Development Authority. Available at: http:// www.sltda.lk/sites/default/files/Annual_Statistical_Report_2010.pdf, (Accessed: 09 July 2016).

Research \& International Relations Division (2012) Annual Statistical Report, Colombo 03: Sri Lanka Tourism Development Authority. Available at: http://www.sltda.lk/sites/default/files/Annual_Statistical_Report-2012_new.pdf, (Accessed: 09 July 2016).

Research \& International Relations Division (2013) Annual Statistical Report, Colombo 03: Sri Lanka Tourism Development Authority. Available at: http:// www.sltda.lk/sites/default/files/Annual_Statistical_Report-2013.pdf, (Accessed: 09 July 2016).

Research \& International Relations Division (2014) Annual Statistical Report, Colombo 03: Sri Lanka Tourism Development Authority. Available at: http://www.sltda.lk/sites/default/files/Annual_Statistical_Report-2014.pdf, (Accessed: 09 July 2016).

Research \& International Relations Division (2015) Annual Statistical Report, Colombo 03: Sri Lanka Tourism Development Authority. Available at: http://www.sltda.lk/sites/default/files/Tourist_Board_Annual_Report_2015.pdf, (Accessed: 09 July 2016).

SESRIC (2010) International Tourism in the OIC Countries: Prospects and Challenges, Ankara: Statistical, Economic and Social Research and Training Centre for Islamic Countries (SESRIC).

Sri Lanka (2016) Available at: http://whc.unesco.org/en/statesparties/lk, (Accessed: 25 October 2016).

Sri Lanka Tourist Attractions (2016) Available at: http://www.sltda.lk/sri_lanka _touris_attractions, (Accessed: 09 October 2016).

Tisdell, C. and Bandara, R. (2004) "Tourism as a Contributor to Development in Sri Lanka: An Overview and a Case Study", Working Paper on Economics, Ecology and the Environment, 94, pp. 1-29.

UNWTO (2015) Annual Report 2014, Madrid: United Nations World Tourism Organization (UNWTO). Available at: http://cf.cdn.unwto.org/sites/all/files/pdf/ unwto_annual_report_2014.pdf (Accessed 18 August 2016).

UNWTO (2016) Tourism Highlights, Madrid: United Nations World Tourism Organization (UNWTO). Available at: http://www.e-unwto.org/doi/pdf/10.181 11/9789284418145 (Accessed 08 September 2016).

UNWTO and SNV (2010) Manual on Tourism and Poverty Alleviation, Practical Steps for Destinations, Madrid: the World Tourism Organization and the Netherlands Development Organization. [Online] DOI: 10.18111/9789284413430 (Accessed 05 August 2016).

Welgamage L. and Perera, P. (2015) "Tourism Economics in Sri Lanka: An Econometric Analysis", International Journal of Business and Social Research, 5(1), pp. 90-101. Available at: file:///C:/Users/CTU/Downloads/684-2186-1-PB\% 20(13).pdf (Accessed 10 September 2016).

Wij, I. (2011) Sri Lanka Tourism: Poised for growth, India: HVS.

World Tourism Organization (2014) "International tourism on track to end 2014 with record numbers", UNWTO World Tourism Barometer, 12(December), pp. 1-6. 
Available at: http://tourlib.net/wto/UNWTO_Barometer_2014_06.pdf (Accessed 12 October 2016).

World Tourism Organization (2016) WNWTO Tourism Highlights, Madrid: World Tourism Organization. Available at: http://www.dadosefatos.turismo.gov.br/ima ges/pdf/estatisticas_indicadores/UNTWO_Tourism_Highlights_2016_Edition.pdf (Accessed 23 November 2016).

WTTC (2015) Travel \& Tourism, Economic Impact 2015 - Sri Lanka, London: World Travel \& Tourism Council. Available at: https://www.wttc.org/-/media/files/re ports/economic\%20impact\%20research/countries\%202015/srilanka2015.pdf (Accessed 10 September 2016). 
